\title{
Effect of Mineral Elements Migration on Softening-melting Properties of Ti-bearing High Basicity Sinter
}

\author{
Tingle $\mathrm{LI}^{1,2)}$ Changyu SUN, ${ }^{1,2) *}$ Dong LAN, ${ }^{1,2)}$ Jian SONG, ${ }^{3)}$ Sunny SONG ${ }^{4)}$ and Qi WANG ${ }^{1,2)}$ \\ 1) Key Laboratory of Chemical Metallurgy Engineering Liaoning Province, University of Science and Technology Liaoning, \\ Anshan, Liaoning, 114051 China. \\ 2) School of Materials and Metallurgy, University of Science and Technology Liaoning, Anshan, Liaoning, 114051 China. \\ 3) Panzhihua Steel Vanadium Ironmaking Plant, Panzhihua, 617024 China. \\ 4) Technical Marketing, Rio Tinto Iron Ore, Perth, 6000 West Australia.
}

(Received on July 12, 2018; accepted on October 22, 2018; J-STAGE Advance published date: December 5, 2018)

\begin{abstract}
The mineral elements migration behaviours of Ti-bearing high basicity sinter during softening-melting process, as well as its effect on softening-melting properties, are studied using scanning electron microscope and $\mathrm{X}$-ray diffractometer. We can conclude that both $\mathrm{MgO}$ and $\mathrm{Al}_{2} \mathrm{O}_{3}$ content increase while $\mathrm{TiO}_{2}$ content increases first and decreases later overall in the slag phase from the original state to melting end. At softening stage, some perovskite dissolves into the slag phase and part of $\mathrm{TiO}_{2}$ and $\mathrm{MgO}$ in wustite phase transfer into the slag phase. The low melting temperature of the slag phase is the main factor for the low softening temperatures of $\mathrm{Ti}$-bearing sinter. At melting stage, $\mathrm{TiO}_{2}$ in the slag phase is tiny and changes little. The low liquidus temperature and viscosity of the slag phase result in the low melting start temperature of Ti-bearing sinter. The slag phase melts great earlier than metallic iron while the unfused sponge iron still bounds large amounts of perovskite crystals. And then, iron collapses and releases the restrained crystals at a higher temperature, resulting in the second rise of pressure drop.
\end{abstract}

KEY WORDS: Ti-bearing sinter; softening-melting; mineral elements migration.

\section{Introduction}

Titanium magnetite is a typical complex iron ore that is widely distributed in many countries, such as Australia, Russia and China. ${ }^{1-3)}$ It is usually made into Ti-bearing pellet and high basicity sinter used in the blast furnace (BF) for producing hot metal and slag. ${ }^{4-9)}$ High basicity sinter has been the most popular charging burden of $\mathrm{BF}$ due to its superiority on metallurgical properties, such as good reducibility and high softening-melting temperatures. ${ }^{10}$ ) For BF smelting of Ti-bearing high basicity sinter, the softening-melting behaviours are not only important, but also very complex.

In the past, a large number of researches have been carried out to study softening-melting properties of sinter. It has been reported that softening-melting temperatures could be improved by increasing basicity. ${ }^{11,12)}$ The softening temperatures decreased ${ }^{13-15)}$ and dripping temperature increased ${ }^{16)}$ with increasing $\mathrm{Al}_{2} \mathrm{O}_{3}$ content. Increasing $\mathrm{MgO}$ content could improve softening-melting properties of sinter. ${ }^{17,18)} \mathrm{But}$, the reports about softening-melting behaviours of Ti-bearing high basicity sinter are few relatively. In the study of Bao et al., the Ti-bearing sinter containing high $\mathrm{TiO}_{2}$ content $(11.30 \%)$ had higher softening-melting-dripping tem-

\footnotetext{
* Corresponding author: E-mail: sunchangyu1979@163.com DOI: https://doi.org/10.2355/isijinternational.ISIJINT-2018-498
}

peratures and pressure drop compared to ordinary sinter. ${ }^{19)}$ Recently, $\mathrm{TiO}_{2}$ content in sinter is decreased due to adding ordinary rich ore powder in sintering. The Ti-bearing high basicity sinter with $4.76 \%-6.03 \% \mathrm{TiO}_{2}$ had higher softening start temperature and lower softening end temperature and dripping temperature than ordinary sinter. ${ }^{20)} \mathrm{Y}$. Z. Wang et al. claimed that the softening temperatures were increased with the increase of $\mathrm{w}\left(\mathrm{TiO}_{2}\right)$ in sinter and were higher than that of ordinary sinter. ${ }^{21)}$ The results of softening-melting behaviours of Ti-bearing sinter have not been consensus. In addition, we think that they may not care mineral elements migration and structural changes during softening-melting process, which may be the important root cause for softening-melting properties of Ti-bearing sinter.

In this paper, the mineral elements migration behaviour and mineralogical and structural changes of Ti-bearing high basicity sinter during softening-melting process are investigated to clarify the softening-melting properties. We hope that the results will be helpful to better understand softening-melting behaviours of Ti-bearing sinter in blast furnace.

\section{Experimental}

\subsection{Samples}

One typical Ti-bearing high basicity sinter used in the study is taken from an actual iron and steel plant in China. 
The chemical compositions are shown in Table 1. The $\mathrm{TiO}_{2}$ content is 6.61 mass $\%$. The binary basicity $\mathrm{R}_{2}$ (mass $\% \mathrm{CaO} /$ mass $\% \mathrm{SiO}_{2}$ ) and $\mathrm{Al}_{2} \mathrm{O}_{3}$ content are 1.93 and 3.05 mass\%, approximate to those of the ordinary high basicity sinter ${ }^{15)}$ (sample $\mathrm{C}$ in the literature) respectively.

\subsection{Softening-melting Procedures}

The softening-melting property testing equipment is employed to study mineral elements migration behaviours and mineralogical and structural changes of Ti-bearing high basicity sinter during softening-melting process. The schematic diagrams of the apparatus and experimental conditions are given detailed in elsewhere. ${ }^{15)}$ The sample is heated at $10^{\circ} \mathrm{C} / \mathrm{min}$ below $950^{\circ} \mathrm{C}$, and kept at $950^{\circ} \mathrm{C}$ for 1 hour, and then heated at $5^{\circ} \mathrm{C} / \mathrm{min}$ over $950^{\circ} \mathrm{C}$. The gas flow is changed from $\mathrm{N}_{2}(5 \mathrm{~L} / \mathrm{min})$ to reducing gas composed of $\mathrm{CO}$ and $\mathrm{N}_{2}$ with the ratio $30 / 70(12 \mathrm{~L} / \mathrm{min})$ until the sample temperature reaches $400^{\circ} \mathrm{C}$. The three main parameters including the sample temperature, bed shrinkage ratio $(\Delta \mathrm{h})$ and gas pressure drop $(\Delta \mathrm{P})$ during softening-melting process are continuously recorded.

The whole softening-melting process is divided two stages, softening stage and melting stage. The following indices are adopted to represent softening and melting characteristics of sinter. The sample temperature when $\Delta \mathrm{h}$ reaches $10 \%, \mathrm{~T}_{10 \%}$, is defined as softening start temperature; $\mathrm{T}_{40 \%}$ is defined as softening end temperature when $\Delta \mathrm{h}$ reaches $40 \%$; melting start temperature, $\mathrm{T}_{\mathrm{m}}$, is the temperature at which $\Delta \mathrm{P}$ first begins to steeply rise; and melting end temperature $\mathrm{T}_{\mathrm{f}}$ is the temperature that $\Delta \mathrm{h}$ does not change greatly.

\subsection{Observation of Mineral Elements Migration}

When the whole softening-melting experiment is completed, the graphite crucible is removed from the apparatus and broken to gain residual materials. Several parallel softening-melting experiments are conducted under the same conditions described in section 2.2. As soon as the sample temperature reaches desired temperature $\left(\mathrm{T}_{10 \%}, \mathrm{~T}_{40 \%}\right.$ and $\mathrm{T}_{\mathrm{m}}$ ), the samples are quenched under high $\mathrm{N}_{2}$ flow by turning off the furnace, obtaining interrupted samples at softening stage and melting stage. And then, interrupted samples and residual materials are photographed and separated for further investigation.

The microstructures and minerals of original sinter sample, interrupted samples and residual materials from softening-melting tests are examined using scanning electron microscope (SEM: ZEISS, LIGMA HD) and X-ray diffractometer (XRD: PANalytical, X'pert Powder) respectively. Energy dispersive spectroscopy (EDS: Oxford, $\mathrm{X}$-Max $50 \mathrm{~mm}^{2}$ ) spot and map scanning are also used to observe distribution and migration of mineral elements. By these means, mineral elements migration behaviours of

Table 1. The chemical compositions of Ti-bearing high basicity sinter (mass $\%)$

\begin{tabular}{cccccccccc}
\hline & $\mathrm{TFe}$ & $\mathrm{FeO}$ & $\mathrm{SiO}_{2}$ & $\mathrm{CaO}$ & $\mathrm{MgO}$ & $\mathrm{Al}_{2} \mathrm{O}_{3}$ & $\mathrm{TiO}_{2}$ & $\mathrm{R}_{2}$ \\
\hline Ti-bearing sinter & 49.33 & 7.65 & 5.91 & 11.43 & 2.25 & 3.05 & 6.61 & 1.93 \\
Ordinary sinter $^{15)}$ & 54.70 & 9.40 & 5.53 & 10.26 & 2.84 & 3.08 & - & 1.86 \\
\hline
\end{tabular}

Ti-bearing high basicity sinter during softening-melting process could be analyzed.

\section{Results}

\subsection{Softening-melting Experiment}

Figure 1 shows the result of softening-melting experiment of Ti-bearing sinter. The shrinkage $(\Delta \mathrm{h})$ curve in first test is little different from that in repeated test, as is the pressure drop $(\Delta \mathrm{P})$ curve. It is proved that the experimental reliability is acceptable. As the temperature increases up to a specific value, the appearance of some liquid slag in sinter particles results in sinter layer softening under a constant load. Once the molten slag accumulates to some extent, the gas channels are plugged up and $\Delta \mathrm{P}$ begins to rise abruptly. When $\Delta \mathrm{P}$ reaches a maximum value, representing the worst permeability. It is noted that the $\Delta \mathrm{P}$ curve of Ti-bearing sinter exhibits two steeply increases in both first test and second test. In contrast, the $\Delta \mathrm{P}$ curve of ordinary high basicity sinter has just one steeply increase. ${ }^{15)}$ Until the end of the experiment, no dripping phenomenon is found. For Ti-bearing sinter, the sample temperature when $\Delta \mathrm{P}$ second starts to steeply rise, is recorded as $\mathrm{T}_{\mathrm{m} 2}$ and defined as the second melting temperature. Compared to the ordinary sinter, Ti-bearing sinter has lower $\mathrm{T}_{10 \%}, \mathrm{~T}_{40 \%}$ and $\mathrm{T}_{\mathrm{m}}$.

\subsection{Composition and Structure in Softening-melting Process}

XRD analysis of Ti-bearing sinter before reduction is shown in Fig. 2. The diffraction peaks due to magnesioferrite, hematite, perovskite and calciumferrite are observed. Compared with relative peak intensity of the main minerals in ordinary sinter, magnesioferrite and perovskite of Ti-bearing are present in comparatively large amounts except for calciumferrite which exists just a little. It is suggested that Ti-bearing sinter would have a relatively lower reducibility.

Figure 3 shows SEM back-scattered electron images of typical structures of the original Ti-bearing sinter. The sinter contains the main structure composed of magnesioferrite, perovskite and amorphous glass phase and a relatively smaller amount of hematite and calciumferrite. EDS maps

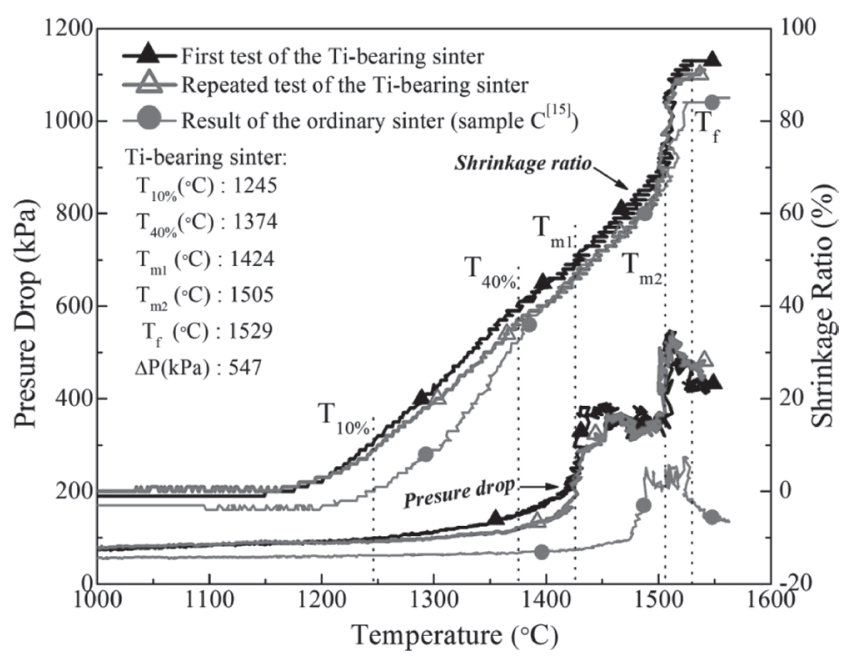

Fig. 1. The softening-melting curves of Ti-bearing sinter. 
of image (a) in Fig. 3 are presented in Fig. 4. And, Table 2 shows the mineral elements contents in each phase of the original sinter. Hereafter in all the tables of this style, every mineral element content is the average of ten values analyzed at different ten positions. Fe concentration in each phase is calculated as $\mathrm{FeO}$ (not $\mathrm{Fe}_{2} \mathrm{O}_{3}$ ) to make it easier to compare the mineral elements content values among interrupted samples. According to the results, $\mathrm{Mg}$ is mainly

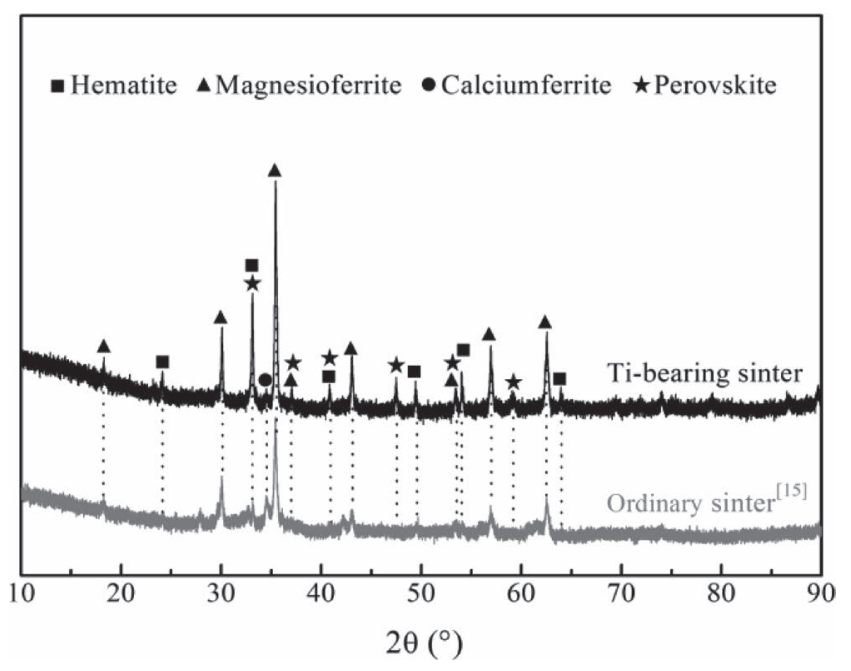

Fig. 2. X-ray diffraction analysis of the original sinter.
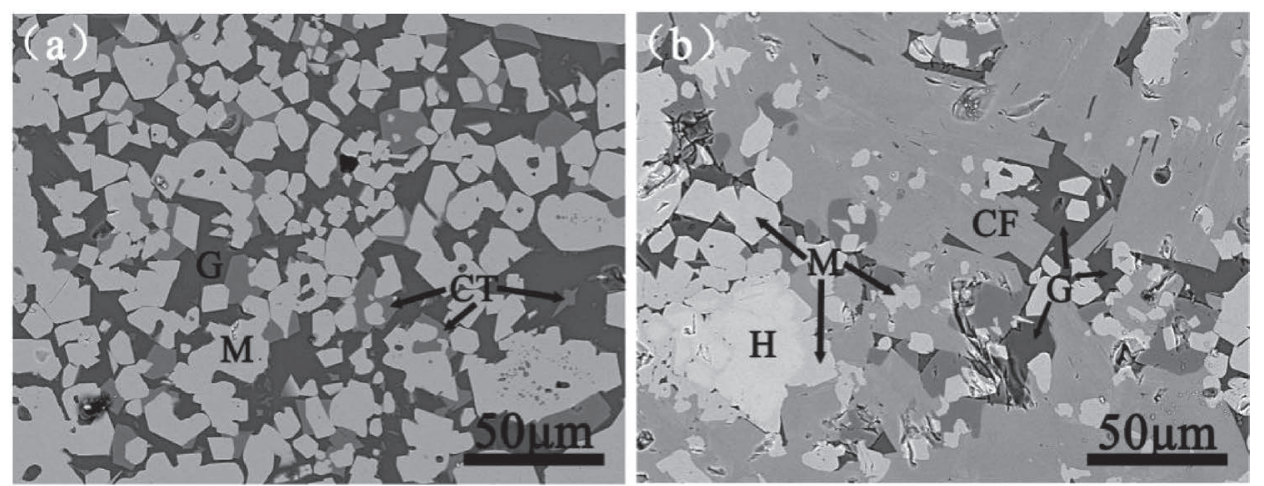

$\mathrm{H}$ : hematite M: magnesioferrite CF: calcium ferrite CT: perovskite G: glass phase

Fig. 3. SEM-BSE images of typical microstructures for original Ti-bearing sinter: (a) the main structure composed of $\mathrm{M}, \mathrm{P}$ and $\mathrm{G}$, (b) small amounts of structure composed of $\mathrm{H}$ and $\mathrm{CF}$.
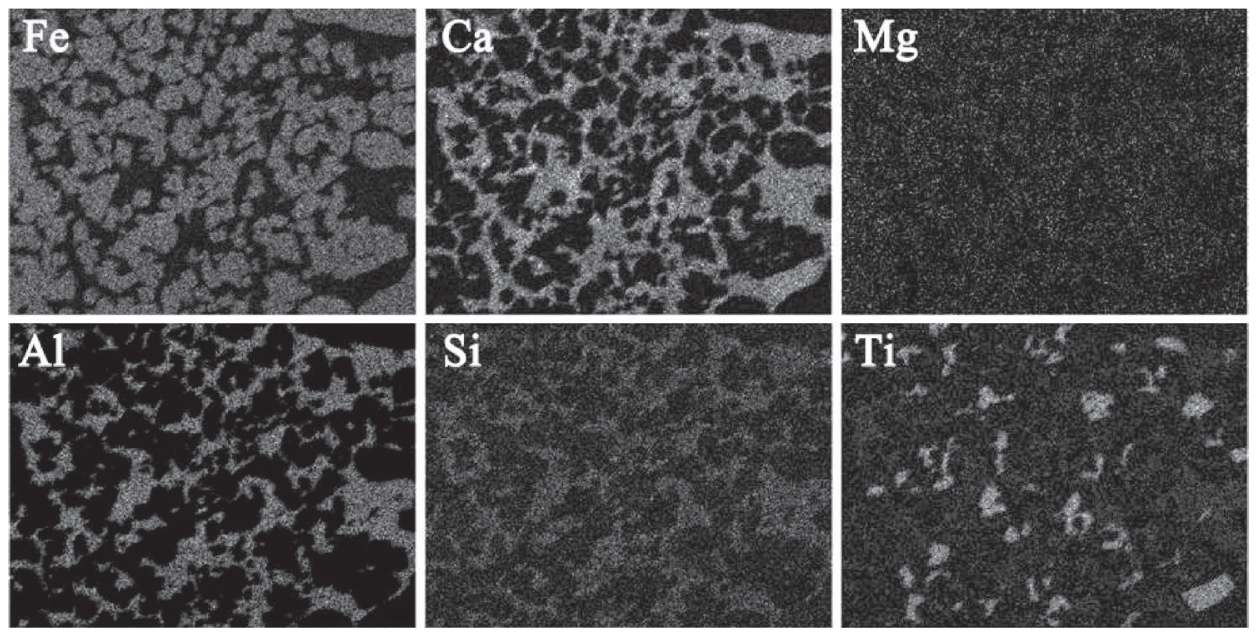

Fig. 4. EDS maps of image (a) in Fig. 3. 
in Table 3, the chemical compositions of $\mathrm{S}_{\mathrm{T} 10 \%}$ and $\mathrm{S}_{\mathrm{T} 40 \%}$ are observed. At 10\%-shrinkage, the reducibility degree of $\mathrm{S}_{\mathrm{T} 10 \%}$ is calculated to be $78.55 \%$ which is lower than that of ordinary sinter $(86.37 \%)$, indicating Ti-bearing sinter is bad reducible at low temperature. This coincides with the mineral microstructure of the original sinter sample mentioned above.

Figure 5 shows XRD analysis of $\mathrm{S}_{\mathrm{T} 10 \%}$ and $\mathrm{S}_{\mathrm{T} 40 \%}$. The main minerals of Ti-bearing sinter interrupted at softening stage are $\mathrm{Fe}, \mathrm{FeO}$, perovskite and melilite. SEM-BSE images of $\mathrm{S}_{\mathrm{T} 10 \%}$ and $\mathrm{S}_{\mathrm{T} 40 \%}$ are shown in Fig. 6. Obviously, from $10 \%$-shrinkage to $40 \%$-shrinkage, the amount of metallic iron increases. There exists a four-phase coexistent microstructure composed mainly of metallic iron, wustite, perovskite and slag phase. Some dot-like substance is found in wustite phase of $\mathrm{S}_{\mathrm{T} 10 \%}$ and it disappears in $\mathrm{S}_{\mathrm{T} 40 \%}$.

The corresponding EDS maps of the images of $\mathrm{S}_{\mathrm{T} 10 \%}$ and $\mathrm{S}_{\mathrm{T} 40 \%}$ are shown in Fig. 7. Ti mainly exists in perovskite while part of $\mathrm{Ti}$ is also picked up by wustite and the slag phase. $\mathrm{Mg}$ is not only distributed in $\mathrm{FeO}$ but also abundantly

Table 3. The chemical compositions of $\mathrm{S}_{\mathrm{T} 10 \%}$ and $\mathrm{S}_{\mathrm{T} 40 \%}$ (mass $\%$ ).

\begin{tabular}{ccccccccc}
\hline $\begin{array}{c}\text { Samples at } \\
\text { softening stage }\end{array}$ & $\mathrm{TFe}$ & $\mathrm{MFe}$ & $\mathrm{FeO}$ & $\mathrm{CaO}$ & $\mathrm{MgO}$ & $\mathrm{Al}_{2} \mathrm{O}_{3}$ & $\mathrm{SiO}_{2}$ & $\mathrm{TiO}_{2}$ \\
\hline $\mathrm{S}_{\mathrm{T} 10 \%}$ & 57.44 & 42.42 & 18.77 & 15.17 & 2.99 & 4.05 & 7.84 & 8.77 \\
$\mathrm{~S}_{\mathrm{T} 40 \%}$ & 59.12 & 53.16 & 7.43 & 15.40 & 3.03 & 4.11 & 7.96 & 8.91 \\
\hline
\end{tabular}

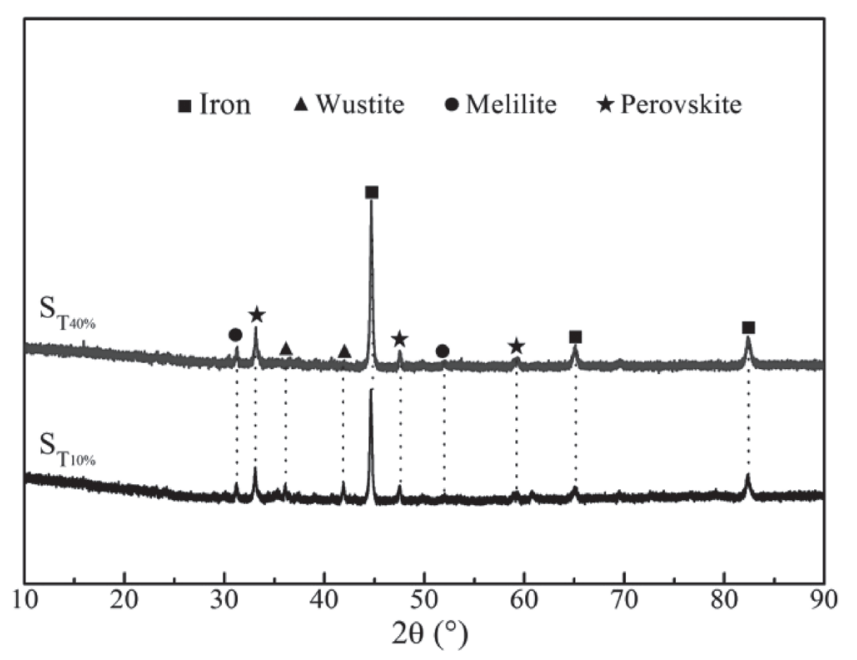

Fig. 5. X-ray diffraction analysis of $\mathrm{S}_{\mathrm{T} 10 \%}$ and $\mathrm{S}_{\mathrm{T} 40 \%}$. picked up by the slag phase. Al is mainly distributed in the slag phase. The mineral elements contents in each phase of $\mathrm{S}_{\mathrm{T} 10 \%}$ and $\mathrm{S}_{\mathrm{T} 40 \%}$ measured by EDS, are presented in Table 4. Fe concentration in wustite, perovskite and slag phase is calculated as FeO. From $\mathrm{S}_{\mathrm{T} 10 \%}$ to $\mathrm{S}_{\mathrm{T} 40 \%}, \mathrm{TiO}_{2}$ content in wustite decreases from $7.05 \%$ to $3.16 \%$ and $\mathrm{MgO}$ content decreases from $6.60 \%$ to $5.16 \%$. Meanwhile, both $\mathrm{TiO}_{2}$ and $\mathrm{MgO}$ content in the slag phase has an increase trend, from $4.41 \%$ to $6.71 \%$ and from $4.86 \%$ to $6.48 \%$, respectively. The binary basicity changes from 1.03 to 1.13 . The average compositions of the dot-like substance is analyzed to be $0.04(\operatorname{mass} \%) \mathrm{CaO}-7.14 \mathrm{MgO}-0.13 \mathrm{Al}_{2} \mathrm{O}_{3}-0.03 \mathrm{SiO}_{2}-$ $18.53 \mathrm{TiO}_{2}-74.13 \mathrm{FeO}$, which has solidus temperature of about $1350^{\circ} \mathrm{C}$ and liquidus temperature of about $1380^{\circ} \mathrm{C}$ based on $\mathrm{FeO}-\mathrm{MgO}-\mathrm{TiO}_{2}$ system. ${ }^{22)}$ This suggests there exist localized areas in wustite containing high $\mathrm{TiO}_{2}$ and $\mathrm{MgO}$ which pass from being into nonbeing at softening range of $1245^{\circ} \mathrm{C}-1374^{\circ} \mathrm{C}$.

After softening, sinter layer enters melting stage. The sinter samples interrupted at $\mathrm{T}_{\mathrm{m}}, \mathrm{T}_{\mathrm{m} 2}$ and the residual materials (near $\mathrm{T}_{\mathrm{f}}$ ), are symboled as $\mathrm{S}_{\mathrm{Tm}}, \mathrm{S}_{\mathrm{Tm} 2}$ and $\mathrm{S}_{\mathrm{Tf}}$, representing the samples at melting stage. The chemical compositions except reduced metallic iron are shown Table 5. As can be seen, there is still much $\mathrm{FeO}$ remaining in $\mathrm{S}_{\mathrm{Tm}}$. The composition of $\mathrm{S}_{\mathrm{Tm} 2}$ is similar to that of $\mathrm{S}_{\mathrm{Tf}}$, showing low $\mathrm{FeO}$ content and indicating little composition evolution from $\mathrm{T}_{\mathrm{m} 2}$ to $T_{f}$. Figure 8 shows $X$-ray diffraction results of $S_{T m}, S_{T m 2}$ and $\mathrm{S}_{\mathrm{Tf}}$. The main minerals are perovskite and melilite, of which the amounts are obviously increased from softening stage to melting stage. It could believe that, as $\mathrm{FeO}$ is reduced, the release of $\mathrm{Ti}$ and $\mathrm{Mg}$ from wustite strengthens formation conditions of perovskite and melilite.

The photos of $\mathrm{S}_{\mathrm{Tm}}, \mathrm{S}_{\mathrm{Tm} 2}$ and $\mathrm{S}_{\mathrm{Tf}}$ are shown in Fig. 9. At $\mathrm{T}_{\mathrm{m}}$, the sample still has granular sinter particles and some small iron beads are observed, indicating that slag/iron separation is not completed. When the temperature reaches $T_{\mathrm{m} 2}$, it is apparent that a large iron bulk generates, which shows slag/iron separation is finished. $\mathrm{S}_{\mathrm{Tf}}$ has a massive structure composed of coke particles, slag and iron. Figure 10 shows SEM-BSE images of $\mathrm{S}_{\mathrm{Tm}}, \mathrm{S}_{\mathrm{Tm} 2}$ and $\mathrm{S}_{\mathrm{Tf}}$ (except for bulk iron). As can be seen, there is a little iron in images of $\mathrm{S}_{\mathrm{Tm} 2}$ and $\mathrm{S}_{\mathrm{Tf}}$, supporting that slag and iron have been separated. Some wustite phase is retained in $\mathrm{S}_{\mathrm{Tm}}$ while no wustite is observed in $\mathrm{S}_{\mathrm{Tm} 2}$ and $\mathrm{S}_{\mathrm{Tf}}$, which are corresponding to the compositions in Table 5. As listed in Table 6, the mineral
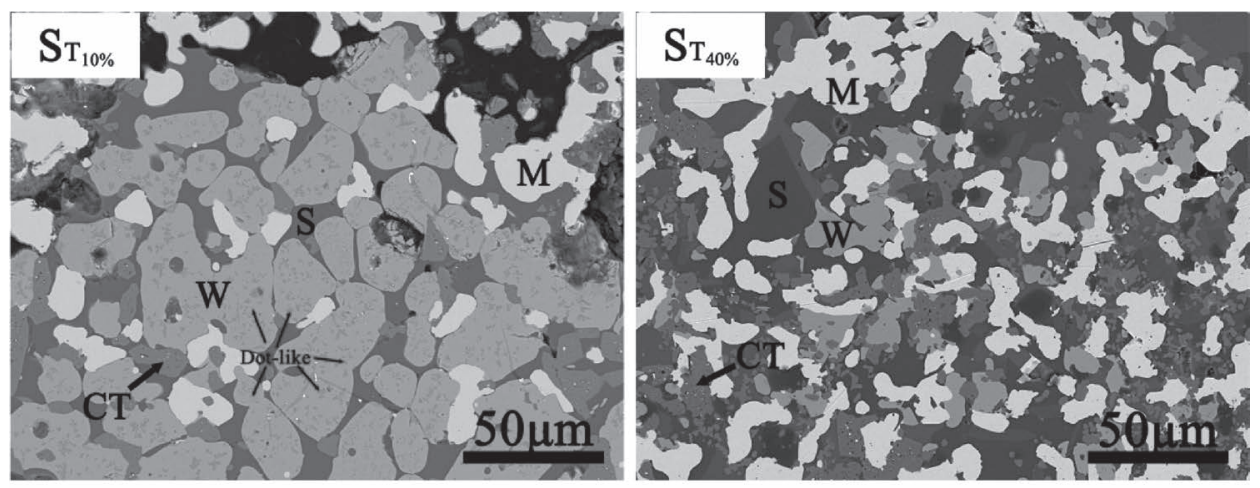

M: metallic iron W: wustite CT: perovskite S: slag phase

Fig. 6. SEM-BSE images of $\mathrm{S}_{\mathrm{T} 10 \%}$ and $\mathrm{S}_{\mathrm{T} 40 \%}$. 

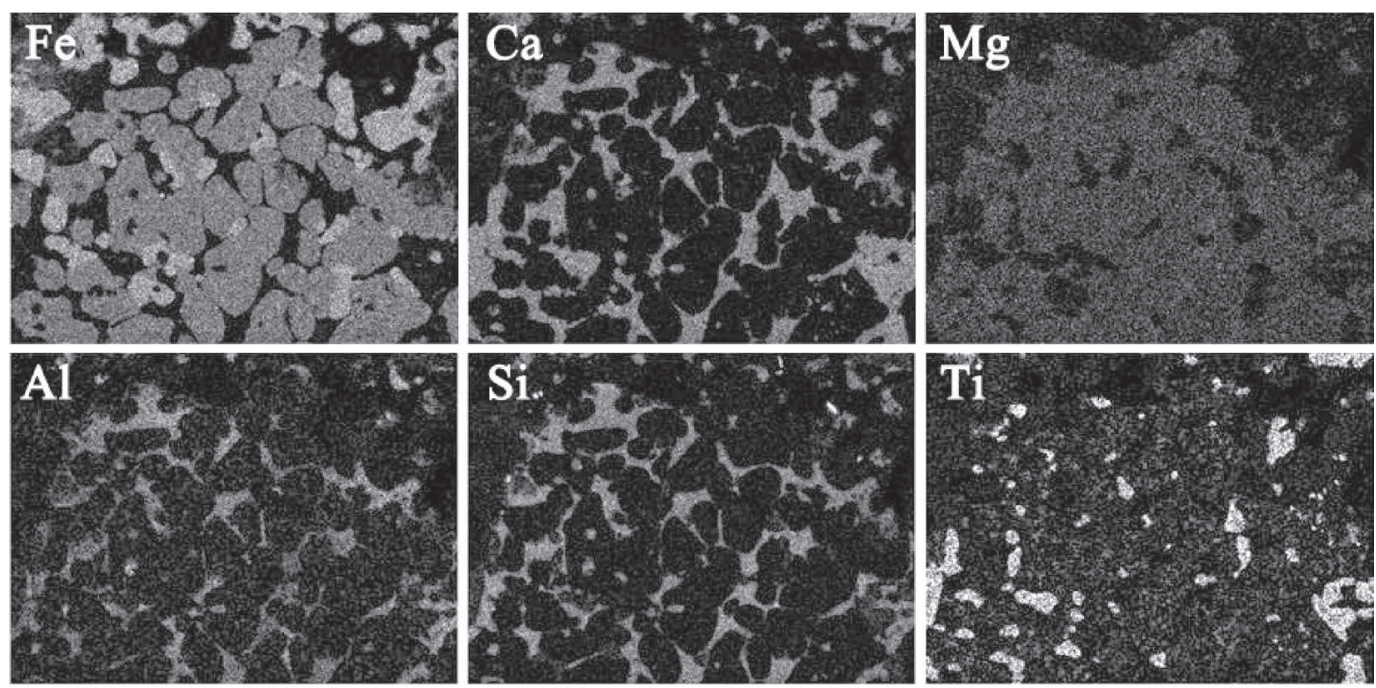

(a)
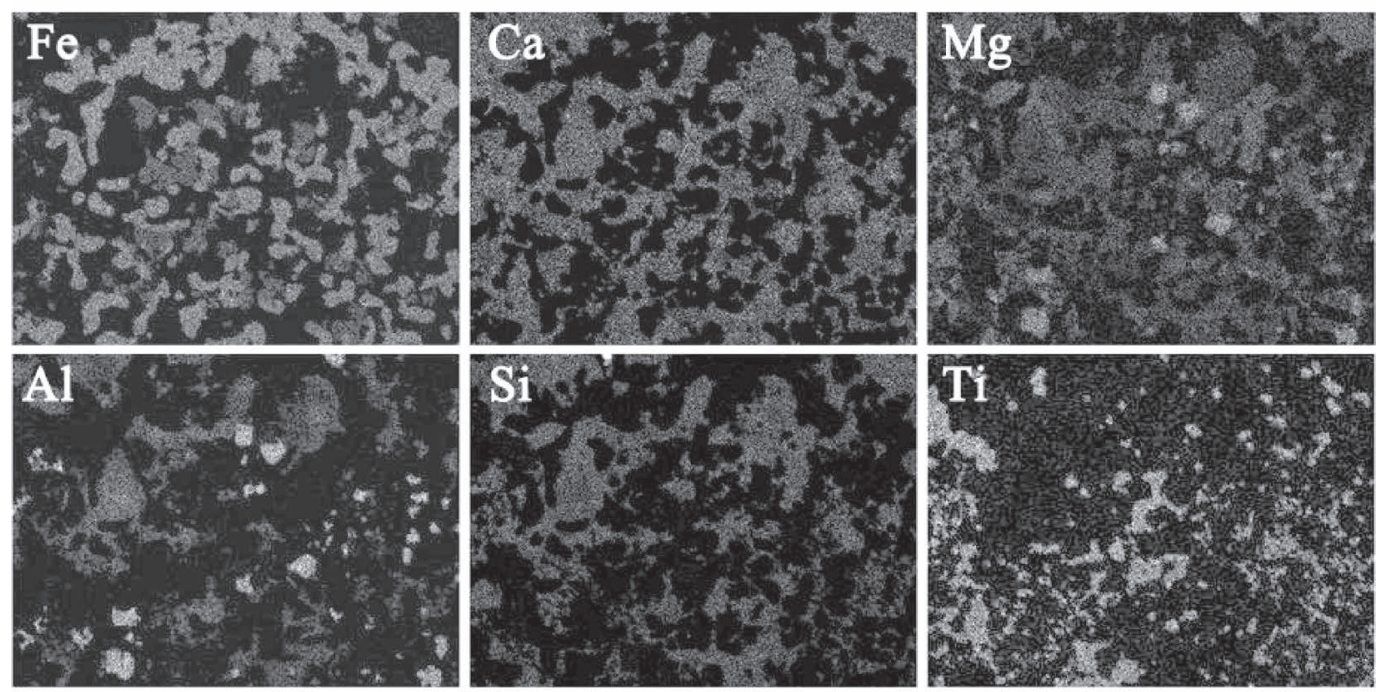

(b)

Fig. 7. EDS maps of the images of (a) $\mathrm{S}_{\mathrm{T} 10 \%}$ (b) $\mathrm{S}_{\mathrm{T} 40 \%}$.

Table 4. The mineral elements contents in each phase of $\mathrm{S}_{\mathrm{T} 10 \%}$ and $\mathrm{S}_{\mathrm{T} 40 \%}(\operatorname{mass} \%)$

\begin{tabular}{ccrrrrrr}
\hline \multirow{2}{*}{$\begin{array}{c}\text { Samples at } \\
\text { softening stage }\end{array}$} & $\begin{array}{c}\text { Identified } \\
\text { phases }\end{array}$ & \multicolumn{6}{c}{ Composition } \\
\cline { 3 - 8 } & & $\mathrm{CaO}$ & $\mathrm{MgO}^{\prime}$ & $\mathrm{Al}_{2} \mathrm{O}_{3}$ & $\mathrm{SiO}_{2}$ & $\mathrm{TiO}_{2}$ & $\mathrm{FeO}$ \\
\hline \multirow{3}{*}{$\mathrm{S}_{\mathrm{T} 10 \%}$} & Wustite & 0.44 & 6.60 & 0.39 & 0.04 & 7.05 & 85.47 \\
& Slag phase & 35.11 & 4.86 & 15.21 & 33.87 & 4.41 & 6.54 \\
& Perovskite & 40.09 & 0.15 & 0.63 & 0.43 & 53.83 & 4.87 \\
& Wustite & 0.07 & 5.16 & 0.39 & 0.05 & 3.16 & 91.17 \\
$\mathrm{~S}_{\mathrm{T} 40 \%}$ & Slag phase & 34.01 & 6.48 & 16.10 & 30.04 & 6.71 & 6.66 \\
& Perovskite & 40.76 & 0.31 & 1.61 & 1.68 & 52.05 & 3.60 \\
\hline
\end{tabular}

Table 5. The chemical compositions of $\mathrm{S}_{\mathrm{Tm}}, \mathrm{S}_{\mathrm{Tm} 2}$ and $\mathrm{S}_{\mathrm{Tf}}$ except reduced metallic iron (mass\%).

\begin{tabular}{ccccccc}
\hline Samples at melting stage & $\mathrm{FeO}$ & $\mathrm{SiO}_{2}$ & $\mathrm{CaO}$ & $\mathrm{MgO}$ & $\mathrm{Al}_{2} \mathrm{O}_{3}$ & $\mathrm{TiO}_{2}$ \\
\hline $\mathrm{S}_{\mathrm{Tm}}$ & 9.59 & 18.27 & 35.33 & 6.95 & 9.43 & 20.43 \\
$\mathrm{~S}_{\mathrm{Tm} 2}$ & 1.79 & 20.09 & 35.42 & 7.29 & 10.02 & 25.40 \\
$\mathrm{~S}_{\mathrm{Tf}}$ & 2.40 & 20.11 & 35.23 & 7.64 & 9.83 & 24.79 \\
\hline
\end{tabular}

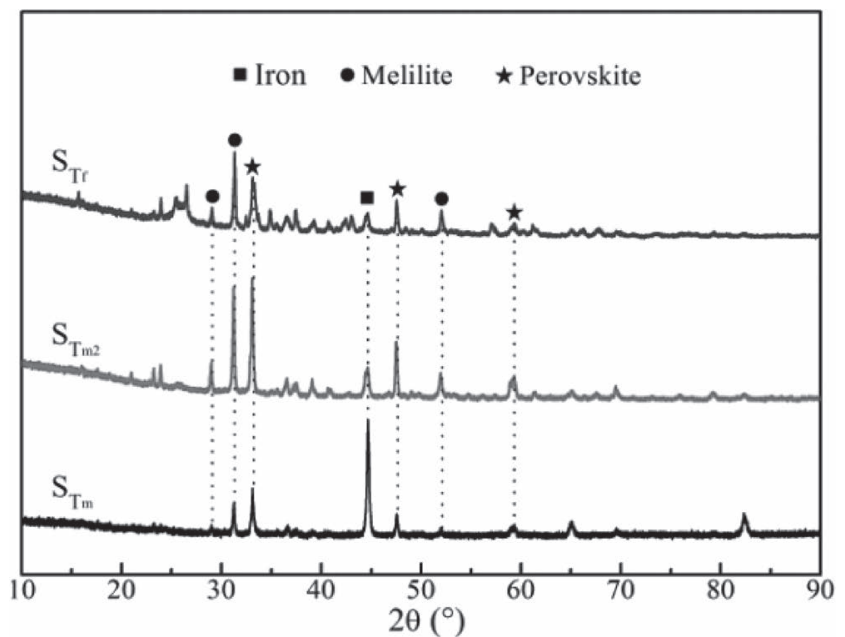

Fig. 8. $\mathrm{X}$-ray diffraction results of $\mathrm{S}_{\mathrm{Tm}}, \mathrm{S}_{\mathrm{Tm} 2}$ and $\mathrm{S}_{\mathrm{Tf}}$.

elements contents in each phase of $\mathrm{S}_{\mathrm{Tm}}, \mathrm{S}_{\mathrm{Tm} 2}$ and $\mathrm{S}_{\mathrm{Tf}}$ are revealed. In $\mathrm{S}_{\mathrm{Tm}}, \mathrm{TiO}_{2}$ content in wustite and the slag phase is tiny, indicating that $\mathrm{TiO}_{2}$ has moved into perovskite after melting start. $\mathrm{TiO}_{2}$ content in the slag phase changes little. 

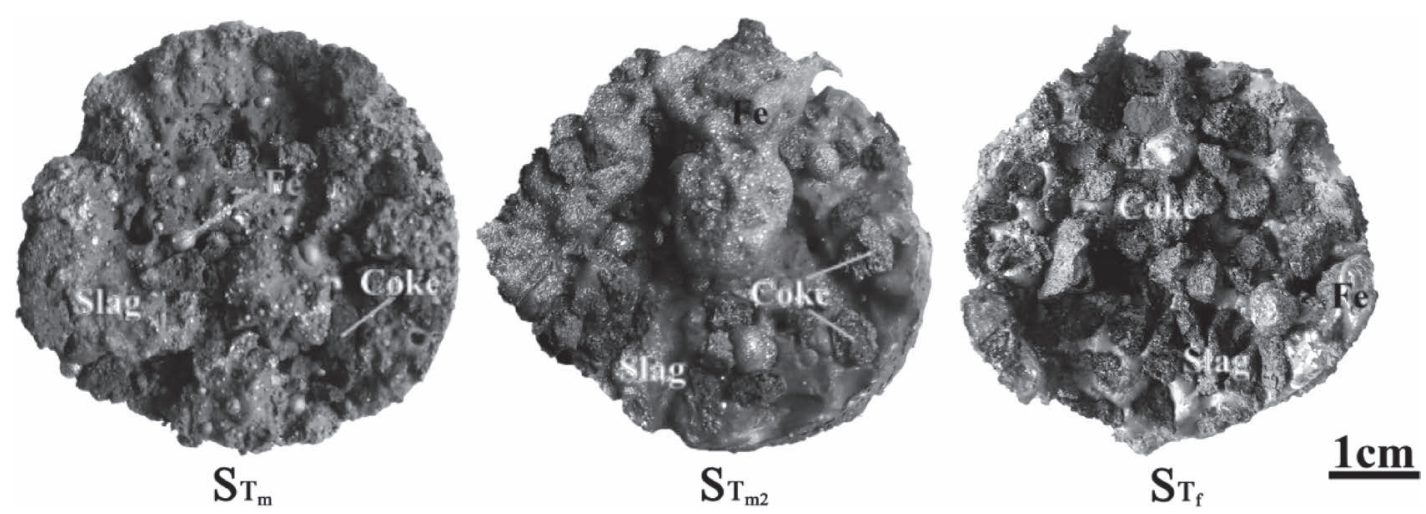

Fig. 9. The photos of $\mathrm{S}_{\mathrm{Tm}}, \mathrm{S}_{\mathrm{Tm} 2}$ and $\mathrm{S}_{\mathrm{T} f}$.
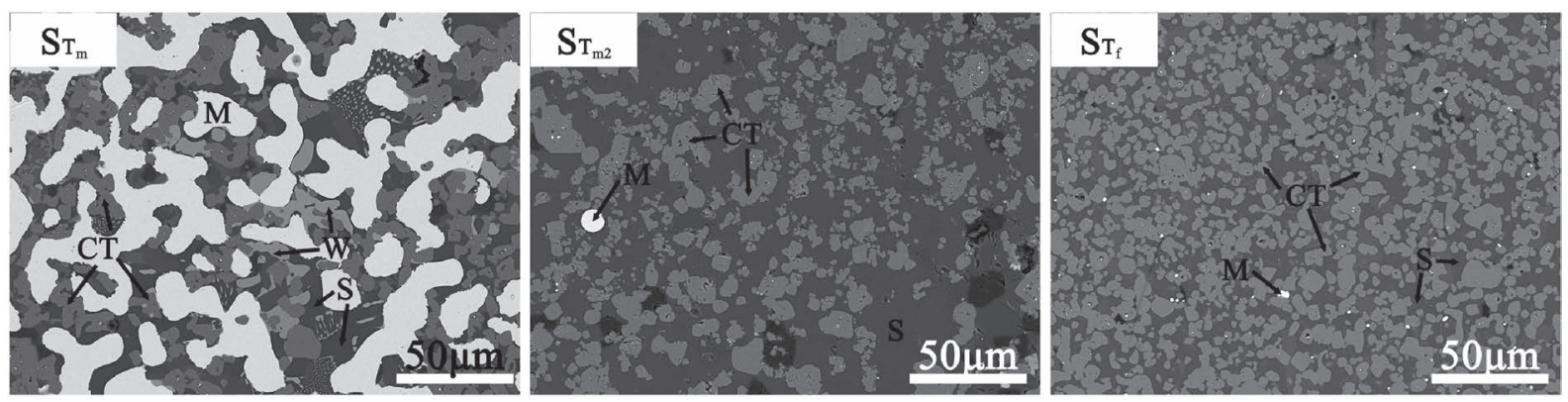

M: metallic iron W: wustite CT: perovskite S: slag phase

Fig. 10. SEM-BSE images of $\mathrm{S}_{\mathrm{Tm}}, \mathrm{S}_{\mathrm{Tm} 2}$ and $\mathrm{S}_{\mathrm{Tf}}$.

Table 6. The mineral elements contents in each phase of $\mathrm{S}_{\mathrm{Tm}}, \mathrm{S}_{\mathrm{Tm} 2}$ and $\mathrm{S}_{\mathrm{Tf}}(\operatorname{mass} \%)$.

\begin{tabular}{|c|c|c|c|c|c|c|c|}
\hline \multirow{2}{*}{$\begin{array}{l}\text { Samples at } \\
\text { melting stage }\end{array}$} & \multirow{2}{*}{$\begin{array}{l}\text { Identified } \\
\text { phases }\end{array}$} & \multicolumn{6}{|c|}{ Composition } \\
\hline & & $\mathrm{CaO}$ & $\mathrm{MgO}$ & $\mathrm{Al}_{2} \mathrm{O}_{3}$ & $\mathrm{SiO}_{2}$ & $\mathrm{TiO}_{2}$ & $\mathrm{FeO}$ \\
\hline \multirow{3}{*}{$\mathrm{S}_{\mathrm{Tm}}$} & Wustite & 0.09 & 11.93 & 0.36 & 0.07 & 1.68 & 85.87 \\
\hline & Slag phase & 35.96 & 7.21 & 18.01 & 32.41 & 0.63 & 5.78 \\
\hline & Perovskite & 40.49 & 0.12 & 1.28 & 1.18 & 52.34 & 4.59 \\
\hline \multirow{2}{*}{$\mathrm{S}_{\mathrm{Tm} 2}$} & Slag phase & 36.03 & 8.19 & 19.77 & 33.23 & 0.66 & 2.12 \\
\hline & Perovskite & 39.97 & 0.78 & 2.28 & 0.02 & 55.43 & 1.52 \\
\hline \multirow{2}{*}{$\mathrm{S}_{\mathrm{Tf}}$} & Slag phase & 37.82 & 10.13 & 19.24 & 30.02 & 0.46 & 2.33 \\
\hline & Perovskite & 41.85 & 0.23 & 2.25 & 0.83 & 54.19 & 0.65 \\
\hline
\end{tabular}

\section{Discussion}

\subsection{Mineral Elements Migration Behaviours}

When Ti-bearing sinter undergoes softening and melting, glass phase in original sinter turns into slag phase, and then the slag phase goes through a development. As shown in Fig. 11, the change of mineral elements contents in glass/ slag phase from the original state to melting end is observed. Both $\mathrm{MgO}$ and $\mathrm{Al}_{2} \mathrm{O}_{3}$ content increase while $\mathrm{TiO}_{2}$ content increases first and decreases later. At softening stage, the extent of the increase of $\mathrm{TiO}_{2}, \mathrm{MgO}$ and $\mathrm{C} / \mathrm{S}$ is larger than that of $\mathrm{Al}_{2} \mathrm{O}_{3}$ and $\mathrm{FeO}$. Combined with the result of Table 4 , it could be believed that part of $\mathrm{TiO}_{2}$ and $\mathrm{MgO}$ in wustite phase transfer into the slag phase at softening stage. As evidence of XRD results, perovskite is always existing in Ti-bearing sinter during the whole softening-melting pro-

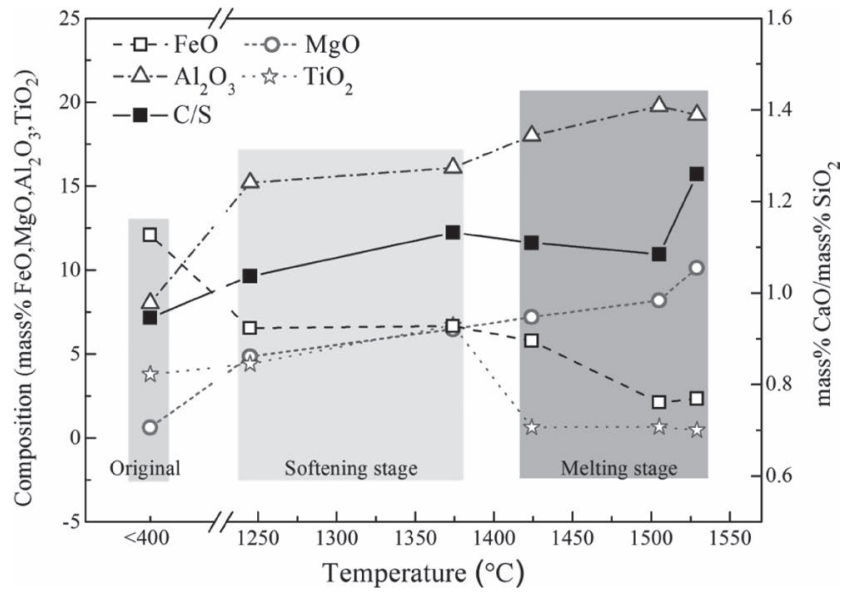

Fig. 11. The change of mineral elements contents in glass/slag phase.

cess. Part of perovskite would dissolve into the slag phase, changing binary basicity and $\mathrm{TiO}_{2}$ content. At melting stage, $\mathrm{TiO}_{2}$ content in the slag phase keeps almost constant. The slag phase of $\mathrm{S}_{\mathrm{Tm}}$ still has a certain amount of $\mathrm{FeO}$ that is close the $\mathrm{FeO}$ content in the slag phase during softening. The elements migration behaviours would change the slag phase property, affecting softening-melting properties of sinter.

\subsection{Effect of Mineral Elements Migration on Softening- melting Properties}

$\mathrm{MgO}$ content in wustite of $\mathrm{Ti}$-bearing sinter at softening stage is about 6 mass $\%$, lower than that (about 14 mass $\%$ ) of ordinary sinter. The diffraction intensity of melilite 

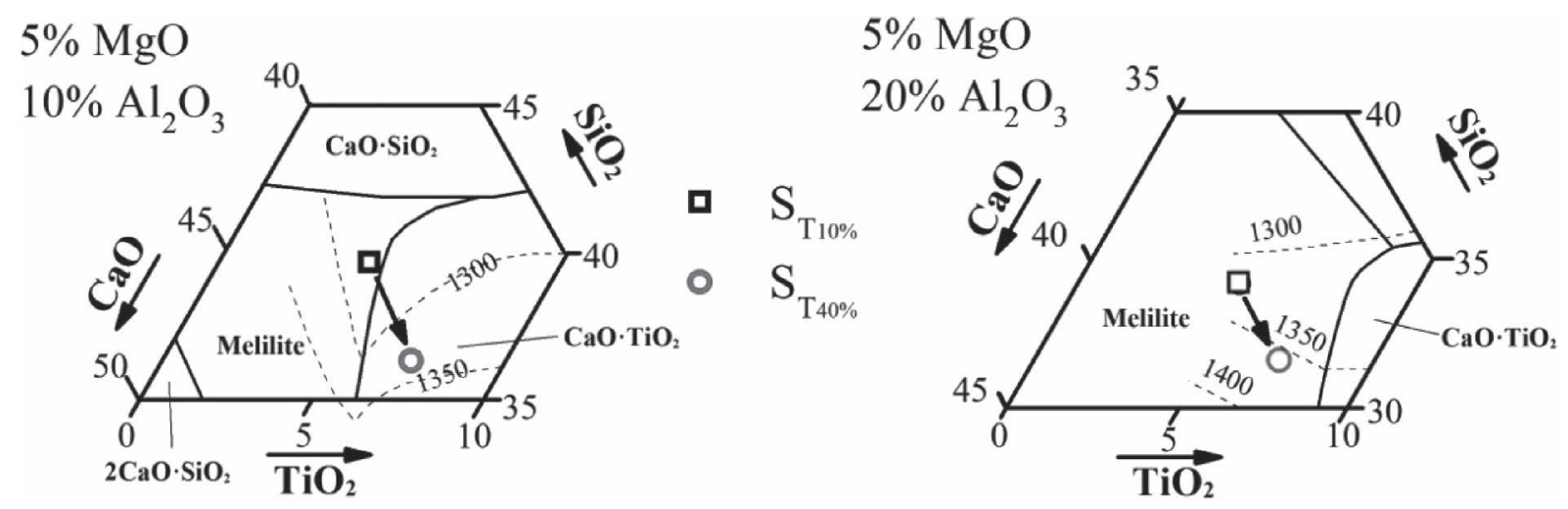

Fig. 12. The phase diagrams of $\mathrm{CaO}-\mathrm{SiO}_{2}-5 \% \mathrm{MgO}-\mathrm{Al}_{2} \mathrm{O}_{3}-\mathrm{TiO}_{2}$ with $10 \% \mathrm{Al}_{2} \mathrm{O}_{3}{ }^{23)}$ and $20 \% \mathrm{Al}_{2} \mathrm{O}_{3}$. ${ }^{24)}$

mentioned in the XRD pattern of $\mathrm{S}_{\mathrm{T} 10 \%}$ and $\mathrm{S}_{\mathrm{T} 40 \%}$ is much stronger than that in ordinary sinter, although Ti-bearing sinter has similar $\mathrm{Al}_{2} \mathrm{O}_{3}$ content and lower $\mathrm{MgO}$ content compared to ordinary sinter. It is suggested that $\mathrm{TiO}_{2}$ existing in wustite could suppress $\mathrm{MgO}$ content in wustite and promote $\mathrm{MgO}$ entering into the slag phase, favoring the formation of melilite. According to the phase diagrams of $\mathrm{FeO}-\mathrm{TiO}_{2}$ system and $\mathrm{FeO}-\mathrm{MgO}$ system, ${ }^{22)} \mathrm{TiO}_{2}$ and $\mathrm{MgO}$ make inverse influences on the melting temperature of wustite when $\mathrm{TiO}_{2}$ or $\mathrm{MgO}$ content is less than 10 mass\%. $\mathrm{MgO}$ in wustite increases the melting temperature of wustite while $\mathrm{TiO}_{2}$ decreases that. In other words, $\mathrm{TiO}_{2}$ would make $\mathrm{FeO}$ easy to dissolve into the slag phase at softening stage, which indirectly leads to low softening temperatures.

From 10\%-shrinkage to $40 \%$-shrinkage, evolution of the slag phase at softening stage is described using phase diagrams of $\mathrm{CaO}-\mathrm{SiO}_{2}-5 \% \mathrm{MgO}-\mathrm{Al}_{2} \mathrm{O}_{3}-\mathrm{TiO}_{2}$ system with different $\mathrm{Al}_{2} \mathrm{O}_{3}$ content level. The phase diagrams with $10 \% \mathrm{Al}_{2} \mathrm{O}_{3}{ }^{23)}$ and $20 \% \mathrm{Al}_{2} \mathrm{O}_{3}{ }^{24)}$ are shown in Fig. 12. The estimated liquidus temperature of the slag phase is in the range of $1270^{\circ} \mathrm{C}-1340^{\circ} \mathrm{C}$ and $1320^{\circ} \mathrm{C}-1370^{\circ} \mathrm{C}$, respectively. What's more, there is some $\mathrm{FeO}$ existing in the slag phase so that the melting temperature would be much lower. In $\mathrm{CaO}-\mathrm{FeO}-\mathrm{TiO}_{2}$ system, ${ }^{22)}$ there is a very low melting point eutectic of $1137^{\circ} \mathrm{C}$. The low melting temperature of the slag phase at softening stage would be the main factor for the low softening temperatures of Ti-bearing sinter.

When Ti-bearing sinter melts, $\mathrm{TiO}_{2}$ in the slag phase is tiny and changes little. As shown in Fig. 13, evolution of the slag phase at melting stage is described in $\mathrm{CaO}-\mathrm{SiO}_{2}-$ $\mathrm{MgO}-20 \% \mathrm{Al}_{2} \mathrm{O}_{3}$ phase diagram. ${ }^{22}$ ) The estimated liquidus temperature of the slag phase in $\mathrm{S}_{\mathrm{Tm}}$ is about $1420^{\circ} \mathrm{C}$. As mentioned above, a certain amount of $\mathrm{FeO}$ retains in the slag phase of $\mathrm{S}_{\mathrm{Tm}}$, decreasing the melting temperature. In addition, some viscosity measurements showed that the slag containing $\mathrm{TiO}_{2}$ and $\mathrm{FeO}$ had a low viscosity at $1450^{\circ} \mathrm{C}$. The viscosity of $\mathrm{CaO}-\mathrm{SiO}_{2}-11.26 \mathrm{wt} \% \mathrm{Al}_{2} \mathrm{O}_{3}-9.13 \mathrm{wt} \% \mathrm{MgO}-$ $5 \mathrm{wt} \% \mathrm{TiO}_{2}-5 \mathrm{wt} \% \mathrm{FeO}$ with $\mathrm{CaO} / \mathrm{SiO}_{2}=1.32$ was 0.263 $\mathrm{Pa} \cdot \mathrm{s}^{25)}$ and that of $\mathrm{CaO}-\mathrm{SiO}_{2}-14 \mathrm{wt} \% \mathrm{Al}_{2} \mathrm{O}_{3}-7 \mathrm{wt} \% \mathrm{MgO}-$ $5 \mathrm{wt} \% \mathrm{FeO}$ with $\mathrm{CaO} / \mathrm{SiO}_{2}=1.35$ was $0.36 \mathrm{~Pa} \cdot \mathrm{s}^{26)}$ This could also result in the low $\mathrm{T}_{\mathrm{m}}$ of $\mathrm{Ti}$-bearing sinter.

The low melting temperature and low viscosity of the slag phase of $\mathrm{S}_{\mathrm{Tm}}$ may lead to the slag phase melting great earlier than metallic iron. The slag phase flows into coke bed and blocks gas channels, resulting the first steeply increase of $\Delta \mathrm{P}$ and little $\mathrm{FeO}$ content in $\mathrm{S}_{\mathrm{Tm}}$ and $\mathrm{S}_{\mathrm{Tm} 2}$. But, the unfused

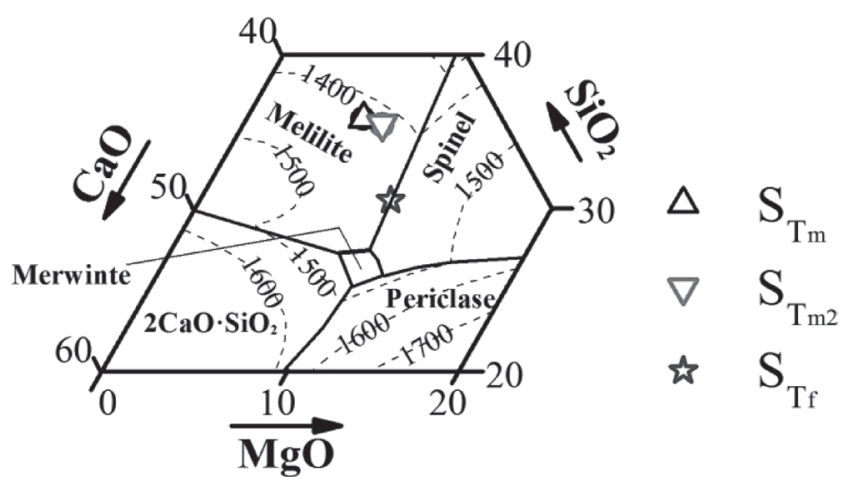

Fig. 13. The phase diagrams of $\left.\mathrm{CaO}-\mathrm{SiO}_{2}-\mathrm{MgO}-20 \% \mathrm{Al}_{2} \mathrm{O}_{3} .{ }^{22}\right)$

sponge iron still bounds large amounts of perovskite crystals. After reaching a higher temperature, iron collapses and releases the restrained crystals, resulting in the second rise of $\Delta \mathrm{P}$ and the sudden increase of $\Delta \mathrm{h}$. This may be the reason for two increases of the $\Delta \mathrm{P}$ curve of Ti-bearing sinter.

From Fig. 13, the liquidus temperature of the slag phase in $\mathrm{S}_{\mathrm{Tf}}$ is estimated to be $1450^{\circ} \mathrm{C}$ approximately, lower than the $\mathrm{T}_{\mathrm{f}}\left(1529^{\circ} \mathrm{C}\right)$. Although the slag phase is liquid, large amounts of perovskite crystals disperse in the slag phase, causing difficult coalescence of the molten iron. Therefore, no dripping behaviour is observed.

\section{Conclusions}

The mineral elements migration behaviours and its effect on the softening-melting properties of Ti-bearing high basicity sinter are investigated and analyzed during softening-melting process. Major findings and conclusions have been obtained.

(1) From the original state to melting end, both $\mathrm{MgO}$ and $\mathrm{Al}_{2} \mathrm{O}_{3}$ content increase while $\mathrm{TiO}_{2}$ content increases first and decreases later overall in the slag phase.

(2) At softening stage, $\mathrm{TiO}_{2}$ existing in wustite could suppress $\mathrm{MgO}$ content and decreases the melting temperature of wustite, which indirectly leads to low softening temperatures. Some perovskite dissolves into the slag phase and part of $\mathrm{TiO}_{2}$ and $\mathrm{MgO}$ in wustite phase transfer into the slag phase. The low melting temperature of the slag phase could be the main factor for the low softening temperatures of Ti-bearing sinter.

(3) At melting stage, $\mathrm{TiO}_{2}$ in the slag phase is tiny and changes little. The low liquidus temperature and viscosity 
of the slag phase of $\mathrm{S}_{\mathrm{Tm}}$ result in the low melting start temperature of Ti-bearing sinter.

(4) The slag phase melts great earlier than metallic iron while the unfused sponge iron still bounds large amounts of perovskite crystals. Iron collapses and releases the restrained crystals at a higher temperature, resulting in the second rise of pressure drop.

\section{Acknowledgements}

The authors gratefully express their appreciation to Panzhihua Steel Vanadium Ironmaking Plant for providing experimental samples and thank Rio Tinto through The Rio Tinto-USTL (University of Science and Technology Liaoning) Joint Research Project and Liaoning Province Natural Fund Guidance Plan Project (20180550599) for supporting this work.

\section{REFERENCES}

1) L. Xiao: Met. Mine, 298 (2001), 28 (in Chinese).

2) H. Du: Theory of Smelting V and Ti-Magnetite by Blast Furnace, Science Press, Beijing, (1996), 1 (in Chinese).

3) M. Chu: Raw Materials, Fuel and Auxiliary Materials for Iron and Steel Metallurgy, Metallurgical Industry Press, Beijing, (2010), 56 (in Chinese).

4) L. Zhang, L. Zhang, M. Wang, G. Li and Z. Sui: Miner. Eng., 20 (2007), 684

5) J. Tang, M. Chu and X. Xue: Int. J. Miner. Metall. Mater., 22 (2015), 371.

6) G. Cheng, X. Xue, T. Jiang and P. Duan: Metall. Mater. Trans. B, 47
(2016), 1713.

7) X. Lv, Z. Lun, J. Yin and C. Bai: ISIJ Int., 53 (2013), 1115.

8) S. Chen and M. Chu: Int. J. Miner. Metall. Mater., 21 (2014), 225.

9) W. Fu and H. Xie: Steel Res. Int., 82 (2011), 501.

10) C. E. Loo, L. T. Matthews and D. P. O'dea: ISIJ Int., 51 (2011), 930.

11) P. Barnaba: Ironmaking Steelmaking, 12 (1985), 53.

12) Y. Iwanaga: Ironmaking Steelmaking, 16 (1989), 392.

13) T. Tsutsumi, Z. Wang, Y. Sasaki, Y. Kashiwaya, K. Ishii and N. Konno: Tetsu-to-Hagané, 84 (1998), 477.

14) M. Hino, T. Nagasaka, A. Katsumata, K. I. Higuchi, K. Yamaguchi and N. Kon-No: Metall. Mater. Trans. B, 30 (1999), 671.

15) T. Li, C. Sun, X. Liu, S. Song and Q. Wang: Ironmaking Steelmaking, 45 (2018), 755.

16) Z. Wang, J. Zhang, H. Zuo, B. Gao, F. Li and R. Wang: Iron Steel, 50 (2015), 20 (in Chinese).

17) B. Nandy, S. Chandra, D. Bhattacharjee and D. Ghosh: Ironmaking Steelmaking, 33 (2006), 111.

18) K. Zhang, S. Wu, W. Huang, X. Liu, J. Zhu and K. Du: 6th Int. Symp. on High-Temperature Metallurgical Processing, Wiley Online Library, (2015), 155. https://link.springer.com/chapter/10.1007/978-3319-48217-0_20, (accessed 2015-03-15).

19) Y. Bao, X. Jia and G. Song: Iron Steel Vanadium Titan., 14 (1993), 1 (in Chinese).

20) W. Yang, G. Yang, H. Xing and X. Li: Iron Steel Vanadium Titan., 38 (2017), 118 (in Chinese).

21) Y. Wang, J. Zhang, Z. Liu, Y. Zhang, D. Liu and C. Du: Iron Steel, 52 (2017), 20 (in Chinese).

22) Slag Atlas 2nd ed., ed. by VDEh Verlag Stahleisen, Düsseldorf, (1995), 70, 81, 130, 145, 158.

23) J. Shi, L. Sun, B. Zhang, X. Liu, J. Qiu, Z. Wang and M. Jiang: Metall. Mater. Trans. B, 47 (2016), 425.

24) L. Sun, J. Shi, B. Zhang, J. Qiu, Z. Wang and M. Jiang: J. Cent. South Univ., 24 (2017), 48.

25) K. Jiao, J. Zhang, Z. Wang, C. Chen and Y. Liu: Steel Res. Int., 88 (2017), 1.

26) J. R. Kim, Y. S. Lee, D. J. Min, S. M. Jung and S. H. Yi: ISIJ Int., 44 (2004), 1291 